\title{
Tumbuhan Mangrove Bermanfaat Obat di Desa Gedangan, Kecamatan Purwodadi, Kabupaten Purworejo, Jawa Tengah
}

\section{Mangrove Plants Use As Medicine In Gedangan Village, Purwodadi District, Purworejo Regency, Central Java Province}

Penulis

Afiliasi

\section{Slamet Mardiyanto Rahayu ${ }^{1 *}$, Sunarto ${ }^{2}$}

${ }^{1}$ Biologi, FMIPA, Universitas Islam Al-Azhar, Mataram, Nusa Tenggara Barat, 83237 Indonesia

${ }^{2}$ Biologi, FMIPA, Universitas Sebelas Maret, Surakarta, 57126, Indonesia

\section{Kata Kunci \\ O Gedangan \\ - Mangrove \\ O Obat}

Keywords

$\rightarrow$ Gedangan

- Mangrove

- Medicine

Diterima : 5 Oktober 2019

Direvisi : 7 Juni 2020

Disetujui : 24 Juni 2020

*Penulis Koresponding Slamet Mardiyanto Rahayu email: slamet.mardiyantorahayu8 4@gmail.com

\section{ABSTRAK}

Ekosistem pesisir memiliki tumbuhan tingkat tinggi seperti mangrove dan lamun. Hutan mangrove merupakan suatu tipe hutan yang berada di daerah pasang surut, terutama di pantai yang terlindung, laguna, muara sungai yang tergenang pasang dan bebas dari genangan pada saat surut, yang komunitas tumbuhannya bertoleransi terhadap garam. Desa Gedangan merupakan salah satu desa di Kecamatan Purwodadi, Kabupaten Purworejo yang memiliki kawasan mangrove. Penelitian ini bertujuan untuk mengetahui jenis-jenis tumbuhan mangrove yang bermanfaat sebagai obat di Desa Gedangan, Kecamatan Purwodadi, Kabupaten Purworejo, Jawa Tengah. Penelitian dilakukan dengan metode jelajah berupa pengamatan atau observasi lapangan di area mangrove Desa Gedangan, Kecamatan Purwodadi, Kabupaten Purworejo, Jawa Tengah. Berdasarkan penelitian diperoleh delapan (8) jenis tumbuhan mangrove yang berkhasiat obat di Desa Gedangan, Kecamatan Purwodadi, Kabupaten Purworejo, Jawa Tengah, yaitu Rhizophora mucronata, Sonneratia alba, Calotropis gigantea, Nypa fruticans, Acanthus ilicifolius, Hibiscus tiliaceus, Ipomoea pescaprae, dan Wedelia biflora. Jenis-jenis tumbuhan mangrove tersebut secara tradisional dapat dimanfaatkan sebagai obat beri-beri, hepatitis, borok, luka, diare, demam, antibakteri, antiinflamasi, pusing, asma, bronkitis, dispepsia, lepra, tumor, diabetes, sakit perut, sakit gigi, sariawan, TBC, nyeri otot, dan eksim.

\section{ABSTRACT}

Coastal ecosystems have high plant levels, for example mangroves and seagrasses. Mangrove forest is a type of forest located in tidal areas, especially on protected beaches, lagoons, river estuaries that are inundated and free from inundation at low tide, whose plant communities tolerate salt. Gedangan Village is one of the villages in Purwodadi District, which has mangrove areas in Purworejo Regency. This study aims to determine the types of mangrove plants that are useful the Gedangan Village, Purwodadi District, Purworejo Regency, Central Java as medicinal products. The study was conducted using roaming method in the form of observations or field observations in the mangrove area of Gedangan Village, Purwodadi District, Purworejo Regency, Central Java. Based on the research, there were eight (8) types of mangrove plants that were found as medicinal plants in Gedangan Village, namely Rhizophora mucronata, Sonneratia alba, Calotropis gigantea, Nypa fruticans, Acanthus ilicifolius, Hibiscus tiliaceus, Ipomoea pescaprae, and Wedelia biflora. Traditionally, these mangrove species can be used as a medicine items for beri-beri, hepatitis, ulcers, wounds, diarrhea, fever, antibacterial, anti-inflammatory, dizziness, asthma, bronchitis, dyspepsia, leprosy, tumors, diabetes, stomach ache, toothache, thrush, tuberculosis, muscle aches, and eczema. 


\section{PENDAHULUAN}

Ekosistem pesisir memiliki tumbuhan tingkat tinggi seperti mangrove dan lamun. Mangrove didefinisikan sebagai pohon-pohon kayu dan semak belukar yang berkembang di habitat mangrove yang berada di pantai tropis dan subtropis yang didominansi oleh beberapa jenis pohon yang mampu tumbuh dan berkembang pada daerah yang dibatasi temperatur dan memiliki variasi pasang-surut, gelombang, salinitas dan masukkan dari sungai (Alongi 2009). Ekosistem mangrove berfungsi sebagai antroposentris, biogeokimia dan ekologi yang saling mempengaruhi satu sama lain (Field et al. 1998).

Fungsi mangrove berdasarkan antroposentris, diantaranya digunakan sebagai bahan pakan ternak, cinderamata, bahan bangunan, bahan kayu bakar, sumber makanan manusia (Noor et al. 2006) dan bahan obat-obatan tradisional pada zaman dahulu (Bandaranayake 1998). Mangrove yang digunakan sebagai bahan obat-obatan berasal dari buah, daun, kulit batang, dan akar mangrove (Noor et al. 2006).

Indonesia adalah negara yang memiliki distribusi mangrove terbesar di dunia (Polidoro et al. 2010), akan tetapi terdapat jenis mangrove yang belum diketahui penggunaannya dalam hal sumber obat alami (Noor et al. 2006). Ibnu Sina atau Avicennia merupakan seorang Arab yang telah mengembangkan berbagai jenis mangrove untuk bahan medis (Bandaranayake 1998). Mangrove digunakan sebagai bahan medis karena mengandung alkaloid, fenol flavonoid, dan saponin (Bandaranayake 2002) yang dihasilkan dari metabolit sekunder atau yang berasal dari mikroorganisme simbion (endofit) mangrove (Ramasubburayan et al. 2015).
Desa Gedangan merupakan salah satu desa di Kecamatan Purwodadi, Kabupaten Purworejo yang memiliki kawasan mangrove. Sampai saat ini belum ada penelitian identifikasi jenis tumbuhan mangrove yang bermanfaat obat di Desa Gedangan. Oleh karena itu penelitian ini bertujuan untuk mengidentifikasi dan menganalisis jenis-jenis tumbuhan mangrove yang bermanfaat obat di Desa Gedangan, Kecamatan Purwodadi, Kabupaten Purworejo, Jawa Tengah.

\section{METODE}

Penelitian dilakukan dengan metode jelajah berupa pengamatan atau observasi lapangan di area mangrove Desa Gedangan, Kecamatan Purwodadi, Kabupaten Purworejo, Jawa Tengah pada posisi $07^{\circ} 50^{\prime} 16,0^{\prime \prime} S$ $110^{\circ} 00^{\prime} 33,2^{\prime \prime} \mathrm{E}$. Identifikasi jenis tumbuhan mangrove mengacu pada Buku Panduan Pengenalan Tumbuhan Mangrove di Indonesia (Noor et al. 2006). Tumbuhan mangrove yang telah diidentifikasi kemudian ditelaah melalui studi pustaka menggunakan berbagai referensi seperti artikel jurnal ilmiah untuk mengetahui manfaat atau khasiatnya sebagai obat.

Kawasan Mangrove Gedangan terletak di bagian selatan Desa Gedangan. Desa Gedangan berada dalam wilayah administrasi Kecamatan Purwodadi, Kabupaten Purwworejo, Provinsi Jawa Tengah dan mempunyai batas wilayah sebelah utara dengan Desa Jogoresan, sebelah selatan dengan Samudra Hindia, sebelah barat dengan Desa Jatikontal, dan sebelah timur dengan Desa Karanganyar (Gambar 1).

\section{HASIL DAN PEMBAHASAN}

Bagian selatan Desa Gedangan merupakan wilayah pantai yang terdiri dari ekosistem mangrove berada di
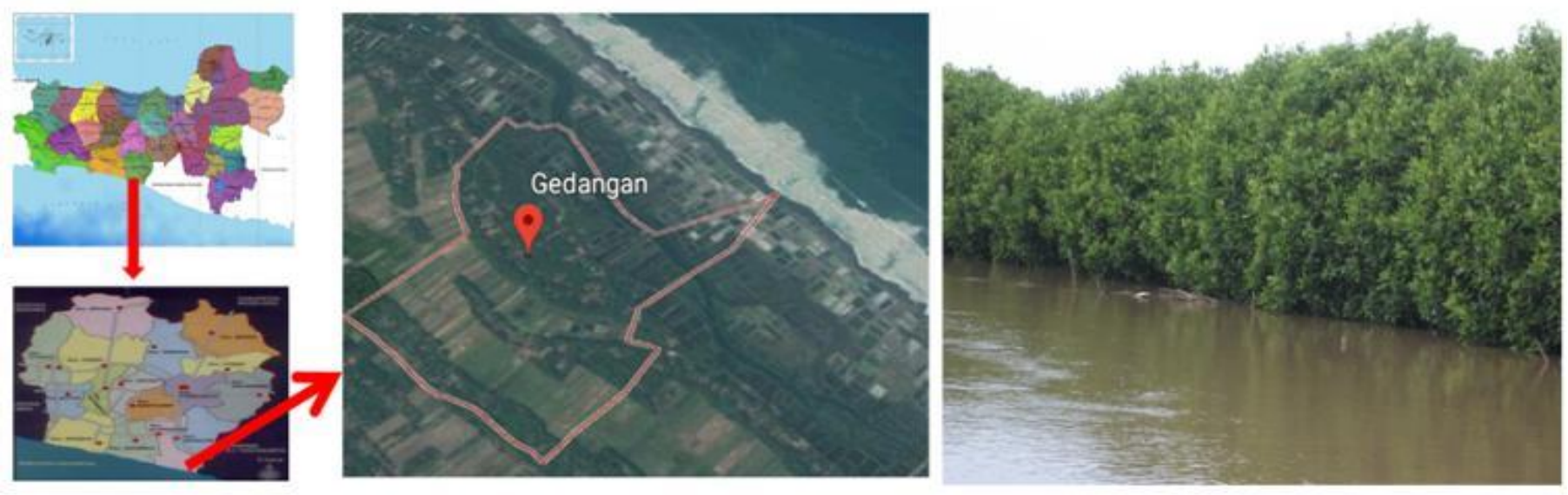

Gambar 1. Lokasi penelitian di area mangrove Desa Gedangan, Kecamatan Purwodadi, Kabupaten Purworejo, Jawa Tengah 
sekitar Sungai Pasir dan telah banyak mengalami konversi lahan menjadi area tambak budidaya udang. Berdasarkan penelitian diperoleh sepuluh (10) jenis tumbuhan mangrove di Desa Gedangan, yaitu Rhizophora mucronata, Sonneratia alba, Nypa fruticans, Gymnanthera paludosa, Calotropis gigantea, Acanthus ilicifolius, Hibiscus tiliaceus, Ipomoea pescaprae, Wedelia biflora, dan Scirpus sp. Dari sepuluh (10) tumbuhan mangrove tersebut, ada delapan (8) jenis tumbuhan yang bermanfaat obat, yaitu Rhizophora mucronata (dongoh korap), Sonneratia alba (bogem), Nypa fruticans (nipah), Acanthus ilicifolius (daruju), Ipomoea pescaprae (katang-katang), Calotropis gigantea (biduri), Hibiscus tiliaceus (waru), dan Wedelia biflora (wedelia).

\section{Rhizophora mucronata (dongoh korap)}

R.mucronata pada bidang medis berpotensi sebagai obat penyakit beri-beri dan haematoma (kulit batang); hepatitis (kulit batang, bunga, daun, akar); borok (kulit batang) (Purnobasuki 2005). R.mucronata merupakan salah satu spesies mangrove yang memiliki sifat antibakteri, antivirus dan antijamur. Antibakteri merupakan zat yang dapat menghambat atau membunuh bakteri dengan penyebab infeksi. Infeksi disebabkan oleh bakteri atau mikroorganisme yang patogen, dimana mikroba masuk ke dalam jaringan tubuh dan berkembang biak di dalam jaringan. Secara fitokimia $R$. mucronata kaya dengan beberapa macam senyawa seperti tannin, alkaloid, flavanoid, terpenoid, dan saponin (Puspitasari et al. 2012).

R.mucronata berhabitus pohon dengan tinggi dapat mencapai $27 \mathrm{~m}$, Batang mempunyai kulit kayu berwarna gelap hingga hitam dan terdapat celah horizontal. Akar tunjang dan akar udara yang tumbuh dari percabangan bagian bawah. Daun berkulit dengan tangkai daun berwarna hijau. Bentuk daun elips melebar sampai bulat memanjang dengan ujung meruncing. Bunga biseksual, masing-masing menempel pada tangkai individu. Bunga berada di ketiak daun dengan formasi berkelompok. Mahkota bunga berwarna putih sedangkan kelopak bunga berwarna kuning. Benang sari berjumlah 8. Buah berbentuk lonjong/panjang hingga berbentuk telur dengan warna hijau kecoklatan dan biji tunggal (Gambar 2).

\section{Sonneratia alba (bogem)}

Tanaman ini telah digunakan secara tradisional di masyarakat pesisir Indonesia untuk pengobatan luka, diare, dan demam (Noor et al. 2006). Penyelidikan fitokimia pada tanaman genus Sonnetaria telah

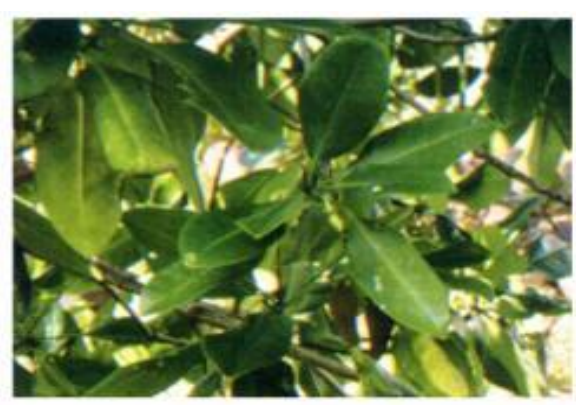

A

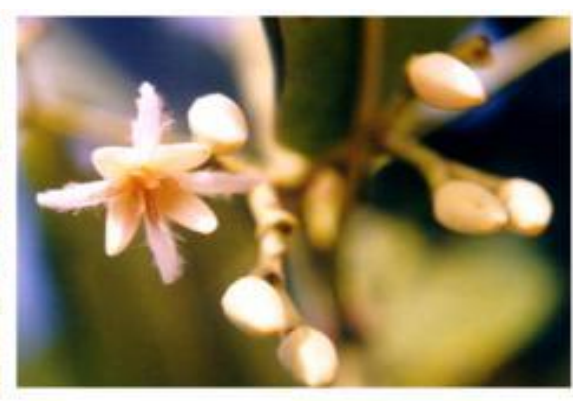

$\mathrm{B}$

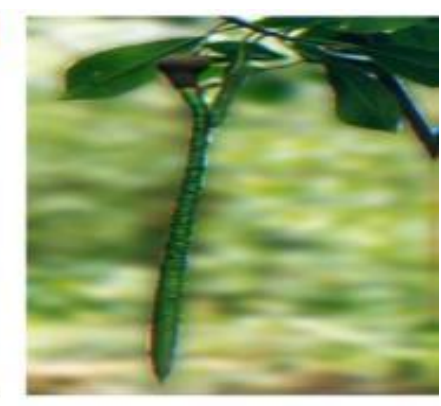

C

Gambar 2. Daun R.mucronata (A), Bunga R.mucronata (B), dan Buah R.mucronata (C)

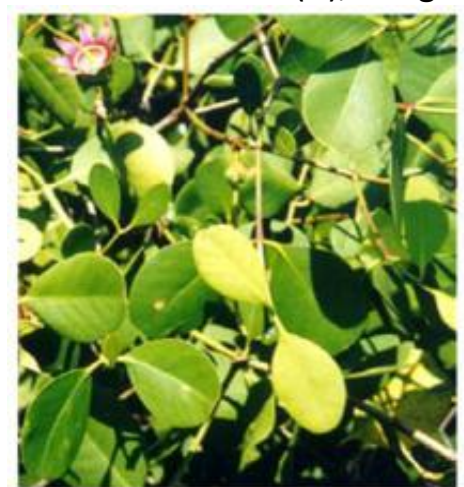

$\mathrm{A}$

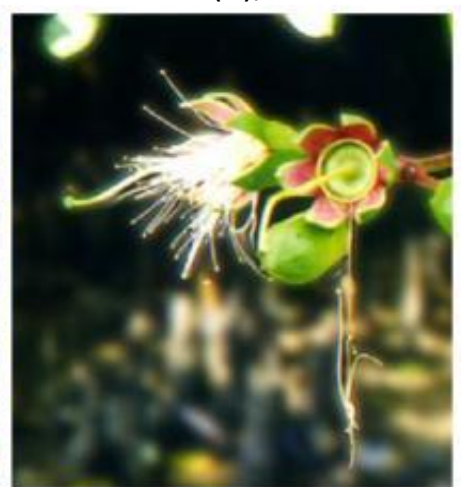

B

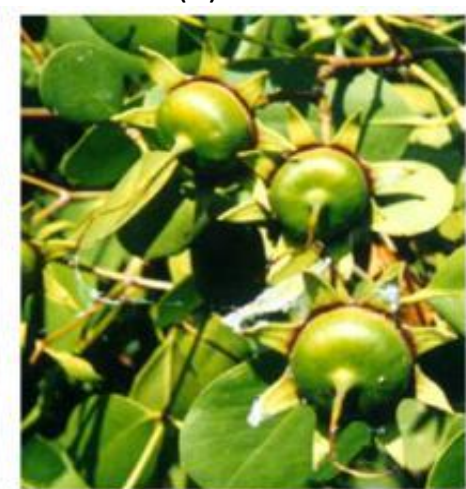

C

Gambar 3. Daun S.alba (A), Bunga S.alba (B), dan Buah S.alba (C)

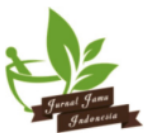


dilaporkan adanya senyawa triterpenoid (Minqing et al. 2009), steroid (Priya et al.2012), asam lemak (Oku et al. 2003), lipid (Chaiyadej et al. 2004), flavonoid (Minqing et al.2009) dan bifenil (Priya et al.2012), serta menunjukkan aktivitas biologis beragam, seperti antibakteri, anti-inflamasi, dan efek insektisidal. Adanya asam 2-kromenkarboksilat juga telah dilaporkan dari jamur endofit, Altenaria sp. dari daun $S$. alba (Kjer et al. 2009).

Berdasarkan penelitian yang dilakukan oleh Milon et al. (2012) menunjukkan bahwa kulit batang S. alba memiliki kemampuan menghambat pertumbuhan jamur Candida albicans, Aspergillus niger dan Saccharomyces cereviceae. Penelitian Saad et al. (2012) menunjukkan bahwa daun $S$. alba juga memiliki kemampuan menghambat pertumbuhan jamur $C$. albicans dan $C$. Neoformans.

S.alba berupa pohon yang tingginya dapat mecapai $15 \mathrm{~m}$. Kulit kayu berwarna putih tua hingga coklat. Akar seprti kabel di bawah tanah dan muncul ke permukaan
Daun berbentuk bulat telur terbalik dengan ujung membundar. Bunga biseksual yang berada di ujung atau pada cabang kecil. Bunga majemuk berkelompok. Mahkota bunga berwarna putih. Bunga berbentuk lonceng. Benang sari banyak dengan ujung berwarna putih dan pangkalnya berwarna kuning. Buah berupa bola dengan banyak biji (Gambar 3).

\section{Calotropis gigantean (biduri)}

Getah warna putih menyerupai susu yang keluar dari batang tanaman diketahui bermanfaat untuk kesehatan, diantaranya sebagai obat herbal penyakit pusing, asma, bronkitis, dispepsia, lepra, tumor, dan berbagai penyakit gangguan pencernaan (Vadlapudi et al. 2012). Hasil uji secara in vitro menunjukkan bahwa ekstrak metanol daun widuri (Calotropis gigantea) memiliki aktivitas antiproliferatif dalam menghambat 6 sel kanker manusia yaitu, MCF-7, MDA-MB-231, Hela, HT-29, SKOV-3 dan HepG2 dengan penghambatan pertumbuhan sel $\leq 50 \%$ (Wong, 2008).

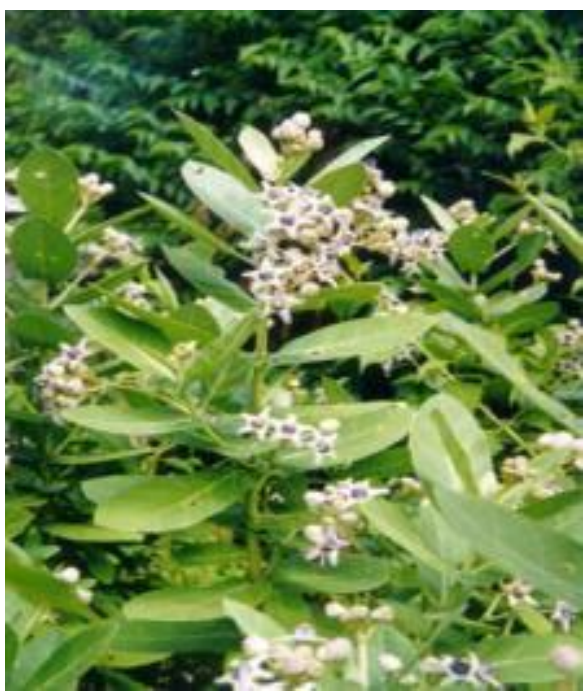

Gambar 4. Daun dan bunga C.gigantea
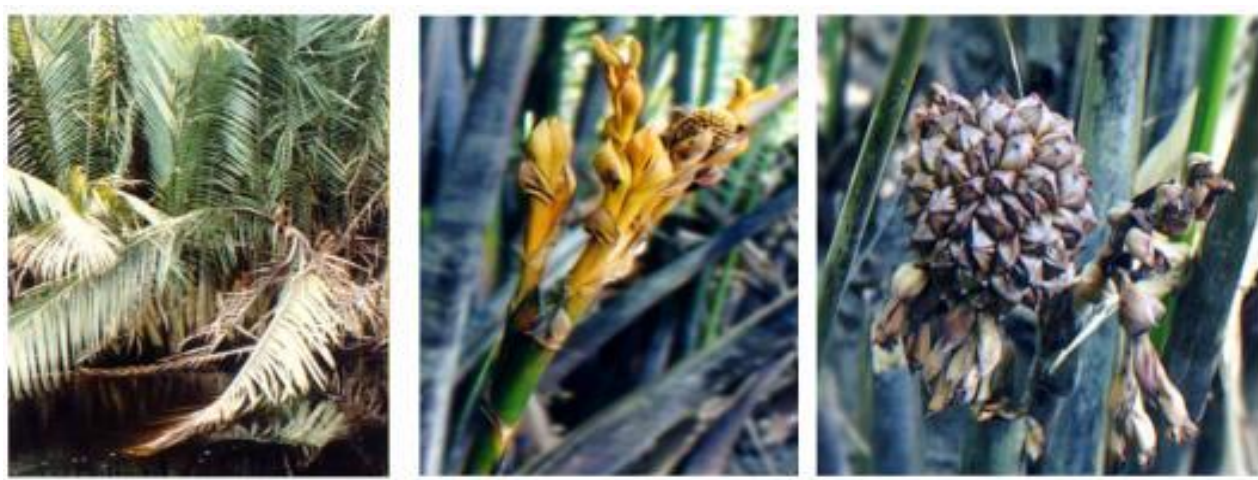

sebagai akar nafas dengan bentuk kerucut tumpul. 
C.gigantea merupakan tumbuhan semak dengan banyak getah. Permukaan daun dilapisi oleh rambutrambut halus berwarna agak putih. Daun berbentuk bulat telur melebar dengan ujung daun membundar. Bunga majemuk dengan mahkota bunga berwarna putih agak ungu dan kelopak bunga berwarna ungu agak putih (Gambar 4).

\section{Nypa fruticans (nipah)}

Tulang anak daun Nipah (N.fruticans) telah dimanfaatkan secara tradisional dan turun-temurun oleh masyarakat pesisir Sungai Kakap sebagai obat sakit gigi dan daun mudanya dimanfaatkan sebagai obat sariawan. Menurut Irmayeni (2010), tanaman Nipah telah dimanfaatkan sebagai obat tradisional seperti obat sakit perut, diabetes dan obat penurun panas. Penelitian yang dilakukan oleh Bakshi dan Chaudhuri (2014) menunjukkan bahwa fraksi metanol, etil asetat, dan aseton daun Nipah menunjukkan aktivitas sebagai antibakteri terhadap bakteri Escherichia coli, Agrobacterium tumefaciens, Streptococcus mutans, Staphylococcus aureus. Ajizat (2004) menyatakan bahwa senyawa flavonoid, saponin, terpenoid, fenolik dan tanin juga merupakan senyawa aktif yang berfungsi sebagai bahan antimikroba. Mekanisme kerja bahan aktif dalam mematikan bakteri dilakukan dengan cara mendenaturasi protein dan merusak membran sel bakteri dengan cara melarutkan lemak yang terdapat pada dinding sel. Tumbuhan nipah (Nypa fruticans) berkhasiat sebagai obat sinusitis (Bayu 2009). Selain itu ekstrak tumbuhan nipah (Nypa fruticans) mampu menghambat penyakit tuberkulosis, penyakit hati (liver), sakit tenggorokan juga berkhasiat sebagai karminatif (dapat membantu pengeluaran angin dari tubuh), penawar racun serta obat penenang (Rahmatullah et al.2010).

N.fruticans merupakan palma tanpa batang di permukaan dan membentuk rumpun. Batang di bawah tanah. Tingginya hingga 4-9 $\mathrm{m}$. Susunan daun seperti daun kelapa berwarna hijau, daun berbentuk lanset dengan ujung meruncing. Bunga berbentuk tandan, bersifat biseksual, tumbuh dari dekat puncak batang. Buah bulat berwarna coklat dan pada setiap buah terdapat satu biji berbentuk telur (Gambar 5).

\section{Acanthus ilicifolius (daruju)}

Bakteri S. aureus resisten metisilin (MRSA) dapat dihambat dari ekstrak daun Acanthus ilicifolius (Prihanto et al. 2012). Buah ditumbuk dan digunakan untuk "pembersih" darah serta mengatasi kulit terbakar. Daun mengobati reumatik. Perasan buah atau akar kadang-kadang digunakan untuk mengatasi racun gigitan ular atau terkena panah beracun. Biji konon bisa mengatasi serangan cacing dalam pencernaan (Noor et al. 2006).

A.ilicifolius merupakan tumbuhan herba. Permukaan daun halus, tepi daun zig zag bergerigi. Daun berbentuk lanset. Mahkota bunga berwarna biru muda kekuningan hingga ungu lembayung. Bunga berbentuk bulir. Buah berwarna hijau berbentuk bulat lonjong (Gambar 6).

\section{Hibiscus tiliaceus (waru)}

Akarnya digunakan sebagai obat demam (Noor et al. 2006). Daun waru (H.tiliaceus) dapat digunakan untuk mengobati TB paru-paru, batuk, sesak napas, radang amandel (tonsillitis), demam, disentri pada anak, muntah darah, radang usus, bisul, abses, dan rambut rontok (Indah \& Darwati 2013). Kulit batang waru mengandung senyawa hibiscusamide, N-trans feruloyltiramine, dan $\mathrm{N}$-cis feruloyltiramine dan bersifat toksik pada sel kanker kolon HT-29 dengan LC50 < 4 $\mu \mathrm{g} / \mathrm{mL}$ (Chen et al. 2006).

H.tiliaceus berhabitus pohon dengan dengan tinggi mencapai $15 \mathrm{~m}$. Kulit kayu berwarna cokelat. Permukaan bawah daun berambut halus dan berwarna agak putih. Daun berbentuk hati dengan ujung meruncing. Bunga berbentuk lonceng berada di ketiak daun. Mahkota bunga berwarna kuning. Kepala putik berwarna ungu (Gambar 7).

\section{Ipomoea pescaprae (katang-katang)}

Bijinya dilaporkan sebagai obat yang baik untuk sakit perut dan kram. Daunnya untuk obat reumatik/nyeri persendian/pegal-pegal, wasir dan korengan, sedangkan akarnya sebagai obat sakit gigi dan eksim. Cairan dari batangnya digunakan untuk mengobati gigitan dan sengatan binatang (Noor et al. 2006). Menurut Hutapea (1993) Ipomoea pes-caprae mengandung metabolit sekunder berupa senyawa alkaloid, flavonoid, tanin dan steroid. Ipomoea pescaprae juga mengandung senyawa aktif steroid, alkaloid, terpenoid dan flavonoid yang dihasilkan oleh fraksi dari ekstrak etil asetat (Souza et al. 1999). Agustiningrum (2004) melaporkan bahwa uji aktivitas antioksidan menggunakan metode NBT (Nitroblue tetrazolium) ekstrak kloroform, etil asetat dan metanol dari daun Ipomoea pes-caprae diperoleh aktivitas antioksidan tertinggi pada ekstrak kloroform. Ekstrak tumbuhan Ipomoea pes-caprae pada konsentrasi $20 \%$ efektif dalam menyembuhkan luka terbuka pada punggung kelinci (Muthalib et al. 2013). 


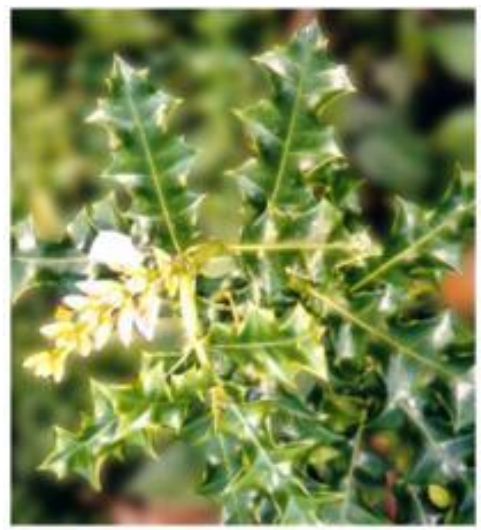

A

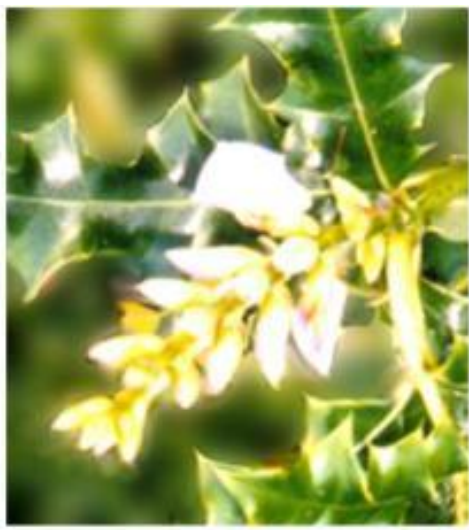

B

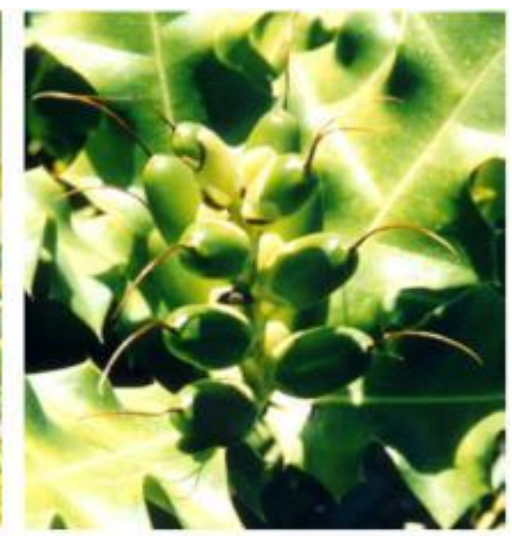

C

Gambar 6. Daun A.ilicifolius (A), Bunga A.ilicifolius (B), dan Buah A.ilicifolius (C)

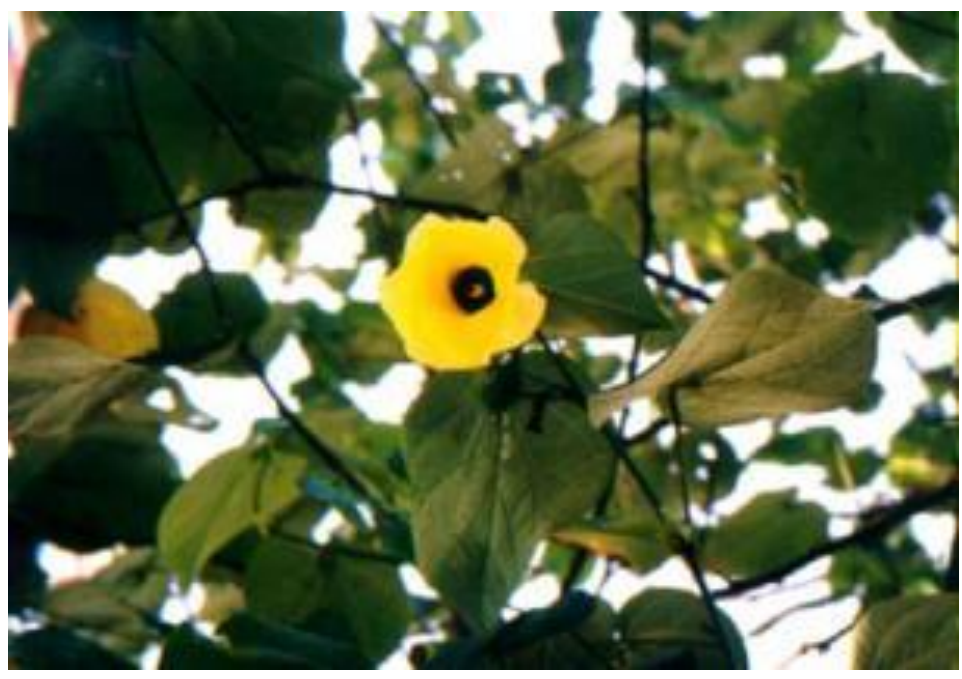

Gambar 7. Daun dan Bunga H.tiliaceus

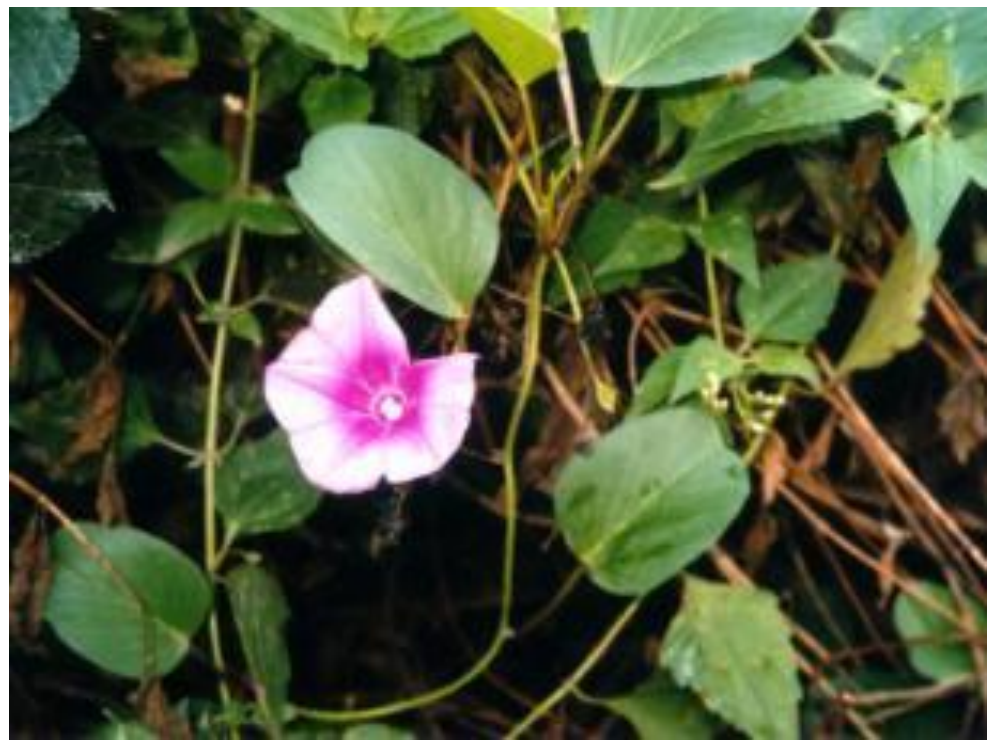

Gambar 8. Daun dan Bunga I.pescaprae

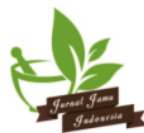




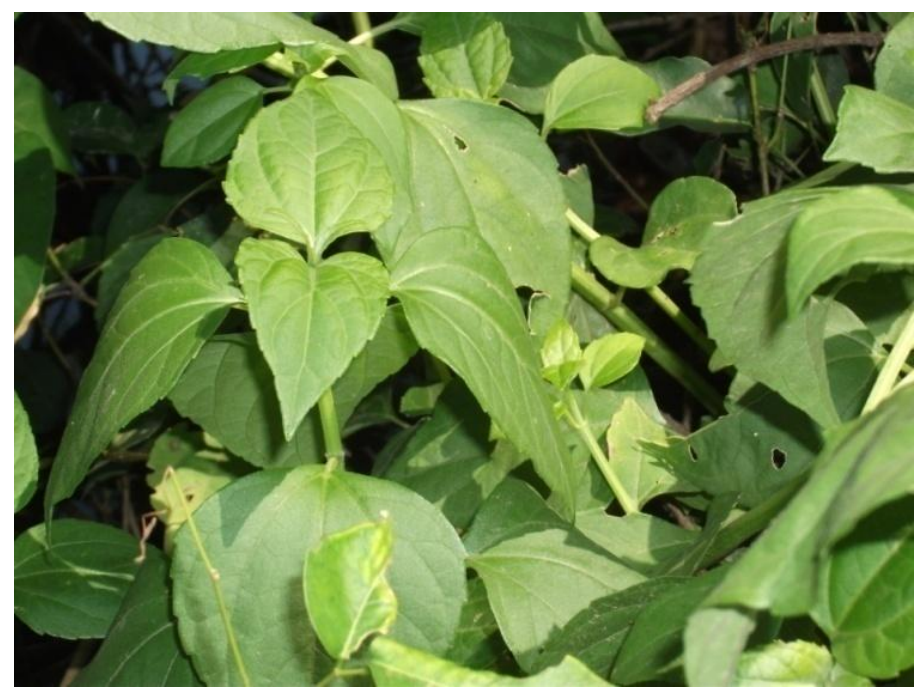

Gambar 9. Daun dan Batang W.biflora

I.pescaprae merupakan tumbuhan herba dengan batang berwarna hijau dan menjalar di permukaan tanah. Akar tumbuh pada ruas batang. Daun berbentuk bulat telur. Bunga berwarna merah muda sampai ungu. Mahkota bunga berbentuk terompet/corong. Buah berbentuk kapsul dengan biji berwarna hitam (Gambar 8).

\section{Wedelia biflora (wedelia)}

Daunnya memiliki kepentingan untuk obat, terutama untuk penggunaan luar. Mengobati luka terpotong atau terkena gigitan. Cairan yang diambil dari daunnya dapat digunakan untuk mengobati sakit perut atau digunakan untuk ibu yang baru bersalin. Akar digunakan untuk obat penyakit kelamin (Noor et al. 2006).

Tumbuhan sernai (W.biflora) mengandung senyawa terpenoid dan hasil penelitian sebelumnya membuktikan bahwa sernai mempunyai aktivitas sebagai antiplasmodium secara in vitro dan in vivo (Isa et al. 2008). Menurut Karira et al. (2004), tumbuhan yang memiliki khasiat sebagai antiprotozoa karena mengandung senyawa seperti alkaloid, terpenoid, kuinolid, dan fenolik.

Razali (2001) meneliti ekstrak dari akar tumbuhan W. biflora diuji aktifitas antimikrobialnya terhadap bakteri Escherichia coli dan Staphylococcus aureus serta jamur Candida albicans. Hasil penelitian menunjukkan bahwa ekstrak metanol akar W. biflora aktif dapat menghambat pertumbuhan kedua jenis bakteri tersebut sedangkan pada $C$. albicans tidak mampu menghambat pertumbuhan jamur tersebut. Elfariyanti (2003) melaporkan bahwa ekstrak $n$-heksana batang tumbuhan W. biflora mampu menghambat aktivitas antimikrobial yang kuat, terhadap $S$. aureus dan terhadap C. albicans.

W.biflora merupakan tumbuhan herba. Batang berwarna hijau. Pada permukaan daun dan batang terdapat beberapa rambut. Tepi daun bergerigi. Bentuk daun bulat telur yang terletak bersilangan. Bunga berwarna kuning cerah (Gambar 9).

\section{SIMPULAN}

Berdasarkan penelitian dapat diketahui bahwa di Desa Gedangan, Kecamatan Purwodadi, Kabupaten Purworejo, Jawa Tengah terdapat delapan (8) jenis tumbuhan mangrove yang bermanfaat obat, yaitu Rhizophora mucronata (dongoh korap), Sonneratia alba (bogem), Nypa fruticans (nipah), Acanthus ilicifolius (daruju), Ipomoea pescaprae (katang-katang), Calotropis gigantea (biduri), Hibiscus tiliaceus (waru), dan Wedelia biflora (wedelia). Bagian tumbuhan mangrove meliputi akar, batang, daun, buah dan biji dapat digunakan sebagai obat tradisional.

\section{UCAPAN TERIMAKASIH}

Terima kasih kepada Pemerintah Desa Gedangan, Kecamatan Purwodadi, Kabupaten Purworejo, Jawa Tengah yang telah memberikan izin penelitian.

\section{DAFTAR PUSTAKA}

D. 2004. Isolasi dan Uji Aktivitas Antioksidan Senyawa Bioaktif Dari Daun Ipomoea pes-caprae [Skripsi]. Bogor (ID): Fakultas Perikanan dan Ilmu Kelautan, Institut Pertanian Bogor. 
Alongi DM. 2009. The Energetics of Mangrove Forests. Ed ke-1. Heidelberg (49): Springer Netherlands.

Ajizat A. 2004. Sensitivitas Salmonella typhirium terhadap ekstrak daun Psidium Guajava. Journal Bioscientive. 1(1): 31-38.

Bandaranayake WM. 1998. Traditional and medicinal uses of mangroves. Mangroves and Salt Marshes. 2:133-148.

Bandaranayake WM. 2002. Bioactivities, bioactive compounds and chemical constituents of mangrove plants. Wetlands Ecology and Management. 10: 421-452.

Bakshi M, and Chaudhuri P. 2014. Antimicrobial Potential of Leaf Extracts of Ten Mangrove Species from Indian Sundarban. International Journal of Pharma and Bio Sciences. 5 (1): 294-304.

Bayu A. 2009. Hutan Mangrove Sebagai Salah Satu Sumber Produk Alam Laut. Oseana. 34(2): 23-15.

Chaiyadej K, Wongthap H, Vadhanavikit S, and Chantrapromma K. 2004. Bioactive constituents from the twigs of Sonneratia alba. Walailak Journal of Science and Technology. 1 (1): 15-22.

Chen JJ, Huang SY, Duh CY, Chen IS, Wang TC, and Fang HY. 2006. A new cytotoxic Amide from the stem wood of Hibiscus tiliaceus. Planta Medica. 72 (10): 935-938.

Elfariyanti. 2003. Isolasi Senyawa Bioaktif Anti Mikrobial Ekstrak $n$-heksana Batang Tumbuhan Wedelia biflora [Skripsi]. Banda Aceh (ID): Fakultas Matematika dan Ilmu Pengetahuan Alam, Universitas Syah Kuala.

Field CB, Osborn JG, Hoffman LL, Polsenberg JF, Ackerly DD, Berry JA, Bjorkman, O, Held, A, Matson, PA, and Mooney, HA. 1998. Mangrove biodiversity and ecosystem function. Gloal Ecology and Biogeography Letter. 7(1): 3-14.

Hutapea JR. 1993. Inventaris Tanaman Obat Indonesia. Ed ke-2. Jakarta (ID): Badan Penelitian dan Pengembangan Kesehatan, Departemen Kesehatan Republik Indonesia.

Indah SY dan Darwati. 2013. Keajaiban Daun Tumpas Tuntas Penyakit Kanker, Diabetes, Ginjal, Hepatitis, Kolesterol, Jantung. Jakarta: Graha Pustaka.

Irmayeni C. 2010. Model Alometrik Biomassa dan Pendugaan Simpanan Karbon Rawa Nipah (Nypa fruticans) [Skripsi]. Medan (ID): Departemen Kehutanan Fakultas Pertanian, Universitas Sumatera Utara.

Isa M, Rinidar, dan Armansyah, T. 2008. Isolasi dan Identifikasi Senyawa Aktif dari Daun Sernai (Wedelia biflora) sebagai Antiplasmodium secara In Vivo
[Laporan Penelitian. Penelitian atas bantuan dana IMHERE]. Banda Aceh (ID): Fakultas Kedokteran Hewan, Universitas Syiah Kuala.

Karira PG, Rukunga GM, Wannyonvi AW, Muregi FM, Gathirwa JW and Omar SA. 2004. Anti-plasmodial activity and toxicity of extract of plants used in traditional malaria therapy in Mern and Kifili Districts of Kenya. Journal of Ethnopharmacology. 34: 160-168.

Kjer J, Wray V, Edrada-Ebel R, Ebel R, Pretsch A, Lin W, and Proksch P. 2009. Xanalteric acids I and II and related phenolic compounds from an endophytic Alternaria $s p$, Isolated from the mangrove plant Sonneratia alba. Journal of Natural Product.s 72 (11): 2053-2057.

Milon A, Muhit A, Goshwarni D, Masud MM, and Begum B. 2012. Antioxidant, cytotoxic and antimicrobial activity of S. alba bark. International Journal of Pharmaceutcal Sciences and Research. 3 (7): 2233-2237.

Minqing T, Haofu D, Xiaoming L, and Bingui W. 2009. Chemical constituents of marine medicinal mangrove plant Sonneratia caseolaris. Chinese Journal of Oceanology and Limnology. 27 (2): 288296.

Muthalib EM, Fatimawali, and Edy HJ. 2013. Formulasi Salep Ekstrak Etanol Daun Tapak Kuda (Ipomoea pes-caprae) dan Uji Efektivitasnya terhadap Luka Terbuka pada Punggung Kelinci. Jurnal IImiah Farmasi. 2(3:79-82).

Noor YR, Khazali M dan Suryadiputra INN. 2006. Panduan Pengenalan Mangrove di Indonesia. Bogor (ID): Ditjen PHKA \& Wetlands International Indonesia Programme.

Oku H, Baba S, Koga H, Takara K, and Iwasaki H. 2003. Lipid composition of mangrove and its relevance to salt tolerance. Journal of Plant Research. 116(1): 3745.

Polidoro BA, Carpenter KE, Collins L, Duke NC, Ellison AM, Ellison JC, Farnsworth EJ, Fernando ES, Kathiresan K, and NKoedam NE. 2010. The Loss of Species: Mangrove Extinction Risk and Geographic Areas of Global Concern. PLOS ONE. 5(4): 1-10.

Prihanto AA, Firdaus M, dan Nurdiani R. 2012. AntiMethicillin Resistant Staphylococcus aureus (MRSA) of Methanol Extract of Mangrove Plants Leaf: Preliminary Report. Drug Invention Today. 4(8): 439440.

Priya PD, Niranjana CS, and Anjali SB. 2012. Sonneratia alba J. Smith., A vital source of gamma linolenic acid 
(GLA). Asian Journal of Pharmaceutical and Clinical Research. 5 (1): 171-175.

Purnobasuki H. 2005. Tinjauan Perspektif Hutan Mangrove. Surabaya (ID): Universitas Airlangga Press.

Puspitasari YE, Hartiati AM, and Suprayitno E. 2012. The Potency of Rhizopora mucronata Leaf Extract as Antidiarrhea. Journal of Applied Science Research. 8 (2): 1180-1185.

Rahmatullah M, Sadeak SkMdl, Bachar SC, Hossain MdT, Al-Mamun A, Montaha, Jahan N, Chowdhury $\mathrm{MH}$, Jahan R, Nasrin N, Rahman M, and Rahman S. 2010. Brine Shrimp Toxicity Study of Different Bangladeshi Medicinal Plants. Advances in Natural and Applied Sciences. 4 (2): 163-173.

Ramasubburayan R, Sumathi S, Bercy DM, Immanuel G, and Palavesam A. 2015. Antimicrobial, antioxidant and anticancer activities of mangrove associated bacterium Bacillus subtilis subsp. subtilis RG. Biocatalysis and Agricultural Biotechnology 4(2): 158-165.

Razali M. 2001. Uji Aktivitas Antimikrobial Ekstrak Akar Tumbuhan Wedelia biflora [Skripsi]. Banda Aceh
(ID): Fakultas Matematika dan Ilmu Pengetahuan Alam, Universitas Syah Kuala.

Saad S, Taher M, Susanti D, Qaralleh H, and Izyani AF. 2012. In vitro antimicrobial activity of mangrove plant Sonneratia alba. Asian Pacific Journal of Tropical Biomedicine. 2 (6):427-429.

Souza MM, Oliveira AM, Cechinel FV, Berti C,Yunes RA, and Krogh R. 1999. Antinociceptive properties of the methanolic extract obtained from Ipomoea pescaprae (L.) R.Br. Journal of Ethnopharmacology. 69 (2000): 85-90.

Vadlapudi V, Behara M, Kaladhar DSVGK, Suresh KSVN, Seshagiri B, and Paul MJ. 2012. Antimicrobial profile of crude extracts Calotropis procera and Centella asiatica against some important pathogens. Indian Journal of Science and Technology. 5 (8): 31323136.

Wong SL. 2008. Diagnosis and Management of Desmoid Tumors and Fibrosarcoma. Journal of Surgical Oncology. 97 (6): 554-558. 